\title{
A CONSTITUIÇÃO DE 1934 NO CONTEXTO DA HISTÓRIA DO CONSTITUCIONALISMO BRASILEIRO
}

\author{
Arnaldo Sampaio de Moraes Godoy*
}

SUMÁRIO: Introdução; 2 A Comissão do Itamaraty; 3 A Assembleia Constituinte e o texto de 1934; 4 Conclusões; Referências.

RESUMO: O artigo estuda o texto constitucional de 1934, com especial ênfase na Comissão do Itamaraty, que redigiu uma proposta originária, alterada por uma Assembleia Nacional Constituinte. Quanto ao texto definitivo, aprovado pela Assembleia, o artigo explora um conjunto de inovações, úteis, e inevitáveis, dado o momento histórico que então se vivia. O objetivo do artigo consiste em tentativa de resgate de informações, relativas à construção desse importante texto constitucional, de pequena existência fática. O método de pesquisa é meramente bibliográfico, resultado de investigações em torno de fontes primárias contidas em documentos da época. Como resultado, o artigo apresenta conjunto de esclarecimentos relativos às origens dos arranjos institucionais relativos à construção de um Estado de Bem-Estar Social. Conclui-se que o texto não subsistiu no tempo por força de amplo leque de compromissos assumidos, inviabilizados no conturbado contexto político da época, que culminou no golpe de Estado de Getúlio Vargas.

PALAVRAS-CHAVE: Assembleia Nacional Constituinte; Comissão do Itamaraty; Constituição Brasileira de 1934; Importância histórica do texto.

\section{THE 1934 CONSTITUTION WITHIN THE CONTEXT OF BRAZILIAN CONSTITUTIONAL HISTORY}

\begin{abstract}
The 1934 text of Constitution is analyzed with special reference to the Itamaraty Commission which had prepared a draft but was altered by the National Constituent Assembly. The essay, investigating a set of useful and unavoidable innovations which were approved by the Assembly, recuperates information, with low phatic existence, on this highly important constitutional text. Current bibliographical method was foregrounded on investigations of primary sources in contemporary documents. Results show a set of explanations related to the origins of institutional arrangements on the construction of a Social Welfare State. The text was not adopted due to the great amount of compromises which were made unavailable within the contemporary political context culminating in Getulio Vargas's coup d'état.
\end{abstract}

\footnotetext{
Livre-docente em teoria geral do estado pela USP; Doutor e Mestre em Filosofia do Direito e do Estado pela PUC/SP; Docente no Centro Universitário de Brasília (UniCEUB), Brasil; E-mail: asmgodoy@gmail.com
} 
KEY WORDS: National Constituent Assembly; Itamaraty Commission; the 1934 Brazilian Constitution; The historical importance of the text; Innovations.

\section{LA CONSTITUCIÓN DE 1934 EN EL CONTEXTO DE LA HISTORIA DEL CONSTITUCIONALISMO BRASILEÑO}

RESUMEN: El artículo estudia el texto constitucional de 1934, con especial énfasis en la Comisión del Itamaraty, que redactó una propuesta originaria, alterada por una Asamblea Nacional Constituyente. Cuanto al texto definitivo, aprobado por la Asamblea, el artículo explora un conjunto de innovaciones, útiles e inevitables, dado el momento histórico que entonces se vivía. El objetivo del artículo consiste en tentativa de rescate de informaciones, relativas a la construcción de ese importante texto constitucional, de pequeña existencia fática. El método de investigación es meramente bibliográfico, resultado de investigaciones en torno de fuentes primarias contenidas en documentos de la época. Como resultado, el artículo presenta conjunto de aclaraciones relativos a los orígenes de los arreglos institucionales relativos a la construcción de un Estado de Bienestar Social. Se concluye que el texto no subsistió en el tiempo por fuerza de amplio abanico de compromisos asumidos, inviabilizados en el conturbado contexto político de la época, que culminó en el golpe de Estado de Getúlio Vargas.

PALABRAS CLAVE: Asamblea Nacional Constituyente; Comisión del Itamaraty; Constitución Brasileña de 1934; Importancia histórica del texto; Innovaciones.

\section{INTRODUÇÃO}

A Constituição de 1934 é documento de época, com características expressivas de seu tempo, marcado por intensa polarização ideológica, revelando arranjos institucionais inovadores, a par de algumas peculiaridades. Algumas, a exemplo da representação classicista, foram de efêmera duração, outras, a exemplo da justiça eleitoral e do mandado de segurança, persistiram, despontando como predicados característicos do constitucionalismo brasileiro.

Precedida por intenso trabalho de uma comissão de notáveis, conhecida como Comissão do Itamaraty, na qual preponderaram João Mangabeira, Carlos Maximiliano, Temístocles Brandão Cavalcanti e Castro Nunes - entre outros - foi debatida em animada Assembleia Nacional Constituinte, que promulgou diverso do do- 
cumento da Comissão; inclusive, pela extensão, e por algumas questões essenciais; no projeto da Comissão não houve espaço para a representação classista na Câmara, modelo que foi adotado pela Constituinte; no projeto da Comissão cogitou-se de um Conselho Supremo, que poderia atuar como um Senado, o que não foi acatado pela Constituinte, que manteve o bicameralismo clássico, que conhecíamos de algum modo desde o Império. Outro exemplo há: a Comissão abonou um Poder Judiciário único (motivo inclusive da demissão de um de seus membros, Arthur Ribeiro de Oliveira, que era Ministro do Supremo Tribunal Federal, defensor da dualidade do Judiciário) e a Assembleia Constituinte o aprovou em duas dimensões, estadual e federal, no que seguimos o modelo norte-americano.

Os debates da Comissão do Itamaraty registram as preocupações que marcavam aquele momento histórico, ainda dependente das incertezas do governo provisório de Getúlio Vargas ${ }^{02}$. O governo provisório de Vargas fora institucionalizado por um decreto de 11 de novembro de 1930, como ato de legalização de um compromisso $^{03}$, acordo que foi frequentemente ressaltado, nas discussões originárias na Comissão do Itamaraty, especialmente nas intervenções de Oswaldo Aranha e de Góes Monteiro.

Com o objetivo de exploração dos grandes temas, momento e particularidades da Constituição de 1934, o presente ensaio pretende discutir o papel e a contribuição dos membros da Comissão do Itamaraty, bem como elencar seus arranjos institucionais de feição inovadora, realçando suas peculiaridades. No pano de fundo pretende-se caracterizar o contexto histórico de sua discussão e curta vigência.

No conjunto das fontes primárias o interessado pode contar com as atas das reuniões da Comissão do Itamaraty, coligidas por José Afonso de Mendonça Azevedo, em edição fac-similar do Senado Federal, junto à Coleção História Constitucional Brasileira ${ }^{04}$. Estão reunidas as atas das reuniões, na íntegra, de 11 de novembro de 1932 (data da primeira reunião) até a $51^{\mathrm{a}}$ e última sessão, realizada em $05 \mathrm{de}$ maio de 1933. São discussões interessantíssimas, nas quais se descortinam fortes dissensos ideológicos que refletiam um quadro político resultante de uma brecha na classe dominante, que culminou com a ascensão de indivíduos de classe média "presentes em todas as fermentações internas" 05.

\footnotetext{
${ }^{02}$ BOURNE, Richard. Getúlio Vargas: a Esfinge dos Pampas. Tradução de Paulo Schmidt e Sonia Augusto. São Paulo: Geração, 2012, p. 53 e ss.; MELLO, José Carlos. Os tempos de Getúlio Vargas. Rio de Janeiro: Topbooks, 2011, p. 223 e ss; FAUSTO, Boris. Getúlio Vargas. São Paulo: Companhia das Letras, 2006, p. 42.

${ }^{03}$ CARONNE, Edgard. A Segunda República - 193-1937. Rio de Janeiro e São Paulo: DIFEL, 1978, p. 17

${ }^{04}$ AZEVEDO, José Afonso de Mendonça. Elaborando a Constituição Nacional: atas da Subcomissão elaboradora do anteprojeto 1932-1933. Brasília: Senado Federal, 2004.

${ }^{05}$ SODRÉ, Nelson Werneck. Formação Histórica do Brasil. Rio de Janeiro: Graphia, 2004, p. 359
} 
Os textos das atas das reuniões são precedidos de um estudo do organizador da edição, Walter Costa Porto, com síntese biográfica dos membros do colegiado, além de uma resenha explicativa das projeções e temas dessas reuniões, das quais pode se colher o núcleo de uma discussão constitucional genuinamente brasileira, substancialmente centrada em problemas nacionais, como se lê nas intervenções de homens públicos como Oswaldo Aranha, Góis Monteiro, Antônio Carlos Ribeiro de Andrada e Afrânio de Mello Franco, seu presidente.

As discussões da Assembleia Constituinte de 1933-34, que se reuniu no Palácio Tiradentes, no Rio de Janeiro, sob a presidência de Antônio Carlos Ribeiro de Andrada, estão disponibilizadas on line no sítio eletrônico do Senado Federal ${ }^{06}$, bem como parcialmente em publicação de 1936 que colaciona as intervenções de Levi Carneiro, deputado constituinte, com ênfase em seus robustos apartes, em tema de presidencialismo, estado de sítio, anistia, imigração estrangeira, entre outros ${ }^{07}$.

Há também ampla bibliografia secundária ${ }^{08}$ que enfoca, prioritariamente, as influências recebidas da Constituição do México (1917), de Weimar (1919) e da Espanha (1931).

A Constituição de 1934 tratou de várias matérias de natureza não constitucional, propiciando texto analítico - no que foi criticada por Carlos Maximiliano - realçando uma tradição do constitucionalismo brasileiro, pródigo em constituições extensas e abundantes em pormenor. Trata-se de um ambiente constitucional de extrato de inovações úteis ou inevitáveis, na precisa expressão de Afonso Arinos de Mello Franco, em biografia sobre seu pai, Afrânio de Mello Franco, presidente de comissão que preparou um anteprojeto que foi discutido por uma Assembleia Nacional Constituinte ${ }^{09}$. A Constituição de 1934 ensaia um Estado de Bem-Estar Social que irá permear os arranjos constitucionais futuros, a exemplo de alguns excertos da própria Constituição de 1988.

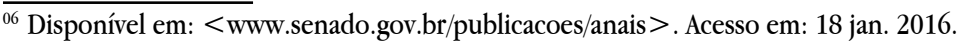

${ }^{07}$ CARNEIRO, Levi. Pela Nova Constituição. Rio de Janeiro: A. Coelho Branco Filho, 1936.

${ }^{08}$ POLETTI, Ronaldo. Constituições Brasileiras, volume III, 1934. Brasília: Senado Federal, 2012; FERREIRA, Waldemar Martins. História do Direito Constitucional Brasileiro. Brasília: Senado Federal, 2003; BONAVIDES, Paulo; ANDRADE, Paes de. História Constitucional do Brasil. Rio de Janeiro: Paz e Terra, 1991; CHACON, Vamireh. Vida e Morte das Constituições Brasileiras. Rio de Janeiro: Forense, 1987; WOLKMER, Antônio Carlos. A questão dos direitos sociais na Comissão Itamarati. Revista de Ciência Política, v. 27, n. 3, set-dez 1984

${ }^{09}$ FRANCO, Afonso Arinos de Mello. Um Estadista da República. Rio de Janeiro: Nova Aguillar, 1976, p. 1044
} 


\section{A COMISSÃO DO ITAMARATY}

Ainda chefiando um Governo Provisório, que organizou com a vitória dos rebeldes que culminou na deposição de Washington Luís, Getúlio Vargas de algum modo cumpriu compromisso assumido ao longo da marcha revolucionária, ao baixar o Decreto $\mathrm{n}^{\circ} 21.402$, de 14 de maio de 1932, fixando o dia 03 de maio de 1933 para a realização das eleições a uma Assembleia Constituinte, criando também uma Comissão para elaborar um anteprojeto de Constituição que seria discutido.

Em seu Diário, em entrada datada de 03 de maio de 1933, Getúlio Vargas registrou a eleição para escolha dos constituintes, que denominou de "grande pleito", anotando que estava "[...] cumprida a palavra do Governo Provisório, apesar de todas as descrenças e dos embaraços criados por uma paradoxal Revolução Constitucionalista, feita preventivamente para realizar uma constitucionalização já com data marcada" ${ }^{10}$. Com alguma euforia, anotou também que os jornais da capital teriam sido lisonjeiros sobre "[...] o pleito e a correção da atitude do governo"11.

A Comissão fora criada sob a presidência do Ministro da Justiça, Francisco Antunes Maciel Júnior, que delegou a uma Subcomissão, chefiada por Afrânio de Mello Franco, a condução dos trabalhos. O grupo se reuniu no Palácio do Itamaraty, onde funcionava o Ministério das Relações Exteriores, o que explica a denominação que recebeu, "Comissão do Itamaraty". Sobre esse colegiado, escreveu-se que

Da Comissão faziam parte personalidades de distintas posições ideológicas; uns da corrente conservadora com raízes na velha tradição republicana e liberal, quais, por exemplo, Mello Franco, Assis Brasil e Carlos Maximiliano; outros, um tanto inclinados ao pensamento social de esquerda, como João Mangabeira e José Américo de Almeida, e finalmente aqueles que mal dissimulavam um nacionalismo de direita tão em voga na época: tal o caso, por exemplo, de Oliveira Vianna, e com certa similitude também o de Góes Monteiro e Temístocles Cavalcanti $^{12}$.

A regulamentação dos trabalhos da Comissão fez-se pelo Decreto $\mathrm{n}^{0} 22.040$,

\footnotetext{
${ }^{10}$ VARGAS, Getúlio. Diário, volume I, 1930-1936. São Paulo: Siciliano e Rio de Janeiro: Fundação Getúlio Vargas, 1995, p. 208-209

${ }^{11}$ Ibidem, 1995, p. 209

${ }^{12}$ BONAVIDES, Paulo; ANDRADE, Paes de. História Constitucional do Brasil. Rio de Janeiro: Paz e Terra, 1991, p. 286.
} 
de $1^{\circ}$ de novembro de 1932, também baixado por Getúlio Vargas, que sublinhava a necessidade de apressar, tanto quanto possível, a elaboração do anteprojeto. Os preceitos regulamentares da Comissão foram dispostos no referido Decreto; os oradores não poderiam falar mais de uma vez em um determinado debate, e nem mais por dez minutos.

Presidida pelo político mineiro Afrânio de Mello Franco, a Comissão contava com importantes expressões da vida política e jurídica da década de 1930, a exemplo de Agenor de Roure, Antônio Carlos Ribeiro de Andrada, Artur Ribeiro de Oliveira, Carlos Maximiliano, José Castro Nunes, Gois Monteiro, João Mangabeira, José Américo de Almeida, Oliveira Vianna, Oswaldo Aranha, Prudente de Moraes Filho, Francisco Solano Carneiro da Cunha e Temístocles Cavalcanti. As intervenções de alguns deles serão tratadas no texto que segue.

Afrânio de Mello Franco, figura central da Comissão, participou ativamente da Revolução de 1930, sendo nomeado por Getúlio Vargas seu Ministro das Relações Exteriores. É pai de Afonso Arinos de Mello Franco e de Virgílio de Mello Franco, também importantes expoentes da vida política brasileira no século XX. Afrânio de Mello Franco se afastou de Getúlio quando este deixou de nomear Virgílio de Mello Franco para a interventoria de Minas Gerais, que ficou vaga, com a morte de Olegário Maciel, em 1933.

Afonso Arinos justificou a escolha de seu pai como presidente da Comissão, porque "todos os requisitos ele apresentava"13. A experiência de quase 25 anos de Parlamento conferia a Afrânio "base para debater com Maximiliano, Prudente ou Mangabeira, os intrincados problemas da intervenção federal, do estado de sítio, do equilíbrio federativo" ${ }^{14}$.

Afrânio defendia a autonomia dos legislativos municipais para a fixação de regras locais, afirmando em uma das reuniões que "o legislativo local deve conhecer melhor as condições da localidade do que o Poder Constituinte, que vai legislar e de maneira igual para todos os municípios, desde os mais remotos do Amazonas até os das fronteiras do Sul" ${ }^{15}$. A edificação constitucional reconhecedora do municipalismo no âmbito do federalismo brasileiro somente ocorrerá com a Constituição de 1988.

Nos debates sobre a transferência da capital para o Planalto Central, Afrânio,

\footnotetext{
${ }^{13}$ FRANCO, Afonso Arinos de Mello. Um Estadista da República. Rio de Janeiro: Nova Aguillar, 1976, p. 1042. ${ }^{14}$ Ibidem, 1976, p. 1043

$1540^{\text {a }}$ Sessão, de 27 de março de 1933.
} 
com base no Conselheiro Lafayette e na história da construção da nova capital mineira, problematizou o assunto, no sentido de que a matéria não seria de índole constituciona ${ }^{16}{ }^{16}$. A efetiva transferência de capital dar-se-á mais tarde, sob a vigência da Constituição de 1946, que também tratou do assunto.

De um modo peculiar Afrânio pretendia que os três poderes fossem denominados de "órgãos da vontade dos Estados"17. Sua tese não triunfou, dado que o projeto da Comissão dispôs que os poderes Legislativo, Executivo e Judiciário seriam limitados, entre si, harmônicos e independentes (art. $1^{\circ}$ do projeto). Afrânio defendia um número de 15 juízes para o Supremo Tribunal Federal, como um máximo quantitativo a ser fixado no texto constitucional, "não havendo razão para admitir a possibilidade de ser necessário mais juízes na Suprema Corte"18. A Comissão aprovou o número de 11 ministros (art. 53 do projeto).

Afrânio também participou ativamente da discussão em torno da criação do mandado de segurança, na qualidade de um habeas corpus civil, exemplificando a situação com situações vividas por servidores públicos que lutavam contra a perda de cargo, no sentido de que

o funcionário demitido ilegalmente requeria habeas corpus, dando como fundamento do pedido que a sua liberdade de entrar na repartição para exercer o seu cargo estava sendo turbada [...] por falta de uma lei clara que defendesse o direito pessoal, eles, como medida urgente, recorriam ao habeas corpus para se oporem ao ato do Poder Executivo ${ }^{19}$.

O mandado de segurança foi aprovado pela Assembleia Constituinte no texto definitivo e se caracteriza como uma das grandes inovações do texto de 1934.

Nas discussões referentes à nacionalidade, Afrânio defendeu que deveríamos adotar critérios de solo e de sangue, porque, país novo, que recebia imigrantes, também queríamos aproveitar os brasileiros que nascessem no estrangeiro, na qualidade de nacionais ${ }^{20}$. No tema da igualdade, Afrânio propôs que se redigisse que "todos os brasileiros são iguais perante a lei, sem privilégio de nascimento, sexo, classe social, riqueza, crença religiosa, ideias políticas, desde que estas não se oponham

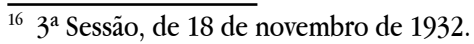

$17 \quad 4^{\mathrm{a}}$ Sessão, de 21 de novembro de 1932.

$1825^{\text {a }}$ Sessão, de 31 de janeiro de 1933.

$1920^{a}$ Sessão, sem indicação de data de realização.

${ }^{20} 18^{a}$ Sessão, sem indicação de data de realização.
} 
à da pátria"21. Essa última cláusula, "deste que estas não se oponham à da pátria" é indicativo de conservadorismo político, sintoma nítido de uma época atemorizada com a expansão do comunismo soviético. Essa ideia foi vitoriosa na Comissão ( $\$ 1^{\circ}$ do art. 102 do Projeto); porém, não passou pelo crivo da Constituinte, que aprovou redação dando conta de que todos eram iguais perante a lei, e que não poderia haver privilégios, nem distinções, por motivo de nascimento, sexo, raça, profissões próprias ou dos pais, classe social, riqueza, crenças religiosas ou ideias políticas (art. $113,1)$.

O ideário de Afrânio alcançava também discussão atualíssima sobre liberdade de ensino religioso; diferenciando aulas de religião e aulas de história da religião, justamente porque "o objetivo do ensino de uma religião é criar prosélitos e não é esse o fito de quem ministra um curso de história das religiões" ${ }^{22}$, pregava a necessidade de uma laicidade mais abrangente. Nas palavras de seu filho,

o esforço de Mello Franco, quase sempre bem-sucedido, era o de coordenar os debates, esclarecer as obscuridades, contornar habilmente os choques, afastar, quando necessário, os desatinos, aceitar as inovações úteis ou inevitáveis, reunir tudo, enfim, no notável projeto que pôde ser submetido à Constituinte ${ }^{23}$.

De fato, Afrânio conduziu os trabalhos da Comissão com muita ponderação, especialmente nas horas de maior atrito, o que ocorreu com as discussões em torno do Judiciário, além de inegáveis oposições de pontos de vista entre liberais como João Mangabeira e conservadores, como Oliveira Vianna; entre posições políticas e de Governo, como as de Oswaldo Aranha e posições técnico-jurídicas, como as de Castro Nunes; entre o amplo conhecimento jurídico de Carlos Maximiliano e uma cultura ostensivamente militar, como a de Gois Monteiro.

A Comissão do Itamaraty contou igualmente com a experiência de Agenor de Roure, estudioso da Constituição de $1824^{24}$ e da Assembleia Nacional Constituinte que preparou a Constituição de $1891^{25}$. Agenor defendia que deveria se deferir exclusivamente ao Legislativo a iniciativa de leis, sem que se impedisse, no entanto, as

$2120^{\mathrm{a}}$ Sessão, sem indicação de data de realização.

${ }^{22} 36^{\text {a }}$ Sessão, sem identificação de data de realização.

${ }^{23}$ FRANCO, 1976, p. 1044

${ }^{24}$ ROURE, Agenor de. Formação Constitucional do Brazil. Rio de Janeiro: Typographia do Jornal do Comércio, 1914

${ }^{25}$ ROURE, Agenor de. A Constituinte Republicana. Brasília: Senado Federal, 1979 
colaborações de associações, escolas e sindicatos ${ }^{26}$. Foi voto parcialmente vencido, dado que a Comissão aprovou que a iniciativa de leis era, além da Assembleia, do Presidente da República, do Conselho Supremo, das Assembleias Legislativas dos Estados, bem como das associações culturais e profissionais devidamente reconhecidas (art. 34, $a$, do Projeto).

Também participou da Comissão Antônio Carlos Ribeiro de Andrada, que mais tarde presidiu a Assembleia Constituinte, e que fora também Presidente de Minas Gerais. Defensor da autonomia político-administrativa dos Estados ${ }^{27}$, ainda que insistisse que à União competia o "comando supremo de todas as forças militares do Brasil"28 Antônio Carlos é o representante do interesse dos Estados mais portentosos, a exemplo de São Paulo e Minas Gerais, nada obstante se tenha a impressão de que o Golpe de 1930 tenha aparentemente diminuído suas respectivas áreas de influência.

Completamente favorável à mudança da capital para o interior ${ }^{29}$, Antônio Carlos também se confessou "um pouco antigo para modificar as suas profundas convicções democráticas" pelo que se colocou abertamente contrário à representação de classes no Parlamento brasileiro, no que restou completamente vencido; sustentando que seria "ponto fundamental da organização de uma democracia que todos os poderes venham soberania popular" que, no seu entender, não se manifestaria simplesmente com a representação classista, o que fez em voto escrito. O político mineiro afirmou que não podia compreender, "para uma mesma Câmara, com os mesmos deputados, e as funções, uma investidura originária de fontes diversas, criando, desde logo, diferenças entre os representantes do mesmo poder" ${ }^{\prime 30}$. Dizendo-se dentro dos princípios democráticos, insistia que o número de representantes seria sempre a consequência do número de habitantes ${ }^{31}$.

Ao que consta, impôs algumas reservas ao irrestrito controle de constitucionalidade, por parte do Supremo Tribunal Federal, com alguma veemência, porque, afirmou "a decretação da tese da inconstitucionalidade das leis pelo Supremo Tribunal Federal exorbita de todos os princípios que [...] têm vigorado no mundo"32.

\footnotetext{
$2613^{\text {a }}$ Sessão, de 22 de dezembro de 1932.

${ }^{27}$ (PEREIRA; FARIA, 1998, p. 429)

$289^{\text {a }}$ Sessão, de 08 de dezembro de 1932.

${ }^{29} 6^{\text {a }}$ Sessão, de $1^{\circ}$ de dezembro de 1932.

${ }^{30} 6^{\text {a }}$ Sessão, de $1^{\circ}$ de dezembro de 1932.

$317^{\text {a }}$ Sessão, de 03 de dezembro de 1932.

$322^{\mathrm{a}}$ Sessão, de 03 de fevereiro de 1932.
} 
João Mangabeira parece ser um dos mais combativos membros da Comissão do Itamaraty. Ligado a Rui Barbosa, a quem biografou, e a quem imputava imortalidade $^{33}$, Mangabeira amalgamou o liberalismo que herdou de Rui com tendências socialistas que trazia de sua trajetória como advogado e político na Bahia. Considerava que a transformação econômica e social conduziria à supressão das desigualdades, por intermédio do processo democrático ${ }^{34}$, premissas que revelam a aproximação entre o ideário socialista e herança programática de Rui Barbosa.

No início dos trabalhos da Comissão Mangabeira reiterou que esta deveria seguir as linhas traçadas pelo Governo Provisório de Vargas (a quem, todavia, sempre combateu), isto é, "federalismo, autonomia municipal, garantias e direitos individuais [...]"; Mangabeira salientou que todas as constituições modernas [tinham] como orientação acabar com as desigualdades sociais, e que se a Constituição brasileira não comungasse dessa lógica, "deixaria de ser revolucionária para se tornar reacionária" ${ }^{35}$. Extremista, à luz de uma comparação com seus colegas de Comissão, Mangabeira entendia que o Estado podia deixar de satisfazer todos os seus endividamentos, com exceção dos compromissos de instrução e saúde de seus habitantes; ainda que não pagasse suas dívidas internas e externas, mas não poderia deixar "[...] sua população morrer miseravelmente à míngua"36. Era dotado de uma retórica extasiante.

Defendia um Governo central forte, no sentido de que "o que é soberano é a União Federal", porque a Nação não seria propriamente um Estado, instância política que exemplificou com o dos flamengos e valões que vivem na Bélgica ${ }^{37}$. Nação seria conceito que alcançaria apenas seu povo, como elemento principal que a compõe ${ }^{38}$. Defendia também uma magistratura nacional, marcada pela unidade da justiça, na qual não haveria espaço para justiças estaduais e justiça federal; condenava a dualidade da magistratura ${ }^{39}$. Exemplificava a precariedade da justiça dualista com ações de nulidade de casamento, que prosperavam em algumas unidades federadas e em outras não, o que suscitava uma corrida para jurisdições mais favoráveis ${ }^{40}$.

\footnotetext{
$\overline{33}$ MANGABEIRA, João. Ruy, o Estadista da República. São Paulo: Livraria Martins Fontes Editora, 1946, p. 13

${ }^{34}$ MANGABEIRA, João. Ideias Políticas de João Mangabeira. Brasília: Senado Federal e Rio de Janeiro: Casa de Rui Barbosa, 1980, p. 71

$351^{\text {a }}$ Sessão, de 11 de novembro de 1932.

$364^{\text {a }}$ Sessão, de 21 de novembro de 1932.

${ }^{37} 3^{\text {a }}$ Sessão, de 18 de novembro de 1932.

38 11 ${ }^{\text {a }}$ Sessão, de 22 de dezembro de 1932.

$3917^{\text {a }}$ Sessão, sem indicação de data de realização.

${ }^{40} 21^{\text {a }}$ Sessão, de 19 de janeiro de 1933.
} 
Defendia magistrados nacionais, que interpretassem e proclamassem o direito, independentes de "[...] corrilhos políticos dos Estados de seus presidentes e dos seus tesouros" ${ }^{\prime 1}$. Mangabeira bem conhecia a realidade das justiças estaduais e do modelo coronelista que ainda triunfava. O coronelismo era um resquício do Império, vinculado ao patrimonialismo central exercido pelo Imperador, título recebido da Guarda Nacional ${ }^{42}$.

Sustentava que a unidade da magistratura era de grande interesse nacional, uma reclamação do povo brasileiro ${ }^{43}$. Aceitava a aposentadoria compulsória aos 70 anos para os Ministros do Supremo Tribunal Federal; rejeitava, porém, iniciativas que pretendiam imunizar aos juízes da incidência de impostos. Ainda em relação ao Judiciário, mais especificadamente no que se refere ao Supremo Tribunal Federal, Mangabeira também rejeitava tendência que pretendia que o Procurador-Geral da República fosse considerado membro de nossa Corte superior ${ }^{44}$.

Apelava para uma Constituição com definições claras, "porque a Constituição deve andar nas mãos do povo e só assim será entendida" ${ }^{* 5}$. Nesse mesmo contexto de defesa de um Governo central forte, defendia que somente a União teria competência para emitir passaportes; deve-se lembrar que à época havia Estados, e até Municípios, que emitiam e controlavam esses documentos ${ }^{46}$. A então ConsultoriaGeral da República havia elaborado vários pareceres tratando do assunto, com o objetivo de sistematizar o modelo brasileiro de confecção, entrega e controle de passaportes para brasileiros. Durante a Primeira República o Governo Provisório de Deodoro da Fonseca havia eliminado o uso do passaporte, porque considerava esse documento manifesta oposição a um regime de completa liberdade individual, a par de um gravame desnecessário e pesado ao emigrante ${ }^{47}$. Estados e alguns municípios se aproveitaram da anomia e passaram a emitir passaportes.

Quanto à representação classicista, tem-se a impressão de que Mangabeira estava dividido; não se animava para votar em favor de uma Câmara inteiramente formada por representantes das classes econômicas e profissionais; porém, invocava que não seria possível iludir a realidade: "não existem, diante do Estado, apenas

\footnotetext{
$\overline{41} 21^{\text {a }}$ Sessão, de 19 de janeiro de 1933.

${ }^{42}$ FAORO, Raymundo. Os Donos do Poder. Rio de Janeiro: Globo, 1997, p. 621

${ }^{43} 21^{\text {a }}$ Sessão, de 19 de janeiro de 1933.

${ }_{44} 25^{\text {a }}$ Sessão, de 31 de janeiro de 1933.

$454^{\text {a }}$ Sessão, de 21 de novembro de 1932.

${ }^{46} 11^{\text {a }}$ Sessão, de 15 de dezembro de 1932.
}

${ }^{47}$ É o conteúdo do Decreto $\mathrm{n}^{\circ} 212$, de 22 de fevereiro de 1890 . O assunto também é exaustivamente tratado em parecer da Consultoria-Geral da República, de autoria de Rodrigo Otávio, datado de 28 de novembro de 1927. 
cidadãos ou indivíduos; existem, também, associações profissionais e sindicatos”48. Era, no entanto, um prático, que dizia que não se dava com estudos arqueológicos, e que examinava a política "à face do presente" ${ }^{\star 49}$. A representação classista não foi aprovada pela Comissão do Itamaraty, o que desagradou a Vargas, que utilizou o Código Eleitoral para implementar esse modelo ${ }^{50}$. A Assembleia Constituinte aprovou o modelo.

João Mangabeira intuía que o mandato era do partido, e não do candidato eleito. Por isso, defendia a cassação de parlamentar que não votasse com o programa da agremiação política que representava; ilustrava sua ideia com o exemplo do político eleito por partido católico que defendesse e votasse pelo divórcio ${ }^{51}$. Mangabeira combatia a limitação à criação de partidos políticos, afirmando que "não se pode proibir a brasileiro nenhum de organizar o partido que entender, sem restrição alguma"52. Em questão atualíssima, financiamento de pleitos eleitorais, Mangabeira pretendia evitar a corrupção dos partidos defendendo disposição constitucional que promovesse a transparência quanto à utilização de recursos financeiros nas campanhas; isto é, afirmava que se precisava "[...] saber de onde provém os recursos para despesas com campanhas eleitorais" ${ }^{33}$.

A correção dos atos presidenciais, e do Poder Executivo de uma maneira geral, segundo Mangabeira, em debates na Comissão, deveria ser feita pelo Supremo Tribunal Federal na hipótese de lesão de direitos individuais, e pelo próprio Congresso, na pressuposição de usurpação de função legislativa, em procedimento de apuração de responsabilidade do Presidente ${ }^{54}$.

O papel do presidente foi discutido recorrentemente, assunto que foi também tratado à luz da experiência alemã, da Constituição de Weimar, então vigente na Alemanha. O regime plebiscitário alemão chegou a ser discutido. Mangabeira ilustrava os contornos da fórmula de Weimar, lembrando que no modelo germânico a Assembleia propunha ao povo, que elegeu o Presidente, "a destituição deste [...] e se o povo decide contra o Presidente, este perde o mandato; se a favor, dissolve-se a Assembleia" $" 55$.

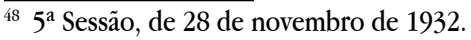

$4914^{\text {a }}$ Sessão, de 26 de dezembro de 1932.

${ }^{50}$ DULLES, John W. F. Vargas of Brazil: a political biography. Austin: University of Texas Press, 1967, p. 131

$5118^{a}$ Sessão, sem indicação de data de realização.

$5224^{\text {a }}$ Sessão, de 27 de janeiro de 1933.

$5311^{\text {a }}$ Sessão, de 15 de dezembro de 1932.

${ }^{44} 14^{\text {a }}$ Sessão, de 26 de dezembro de 1932.

${ }^{5} 16^{\mathrm{a}}$ Sessão, de 02 de janeiro de 1933.
} 
Mangabeira compreendia o Tribunal de Contas como uma delegação do Poder Legislativo na aplicação da despesa e arrecadação da receita, controlando o orçamento, o que justificava a independência da Corte de Contas para com o Executivo; seus membros deveriam ser escolhidos pelo Legislativo, com mandato vitalício ${ }^{56}$. Queria que o Tribunal fosse um órgão que zelasse pelas relações financeiras entre o Executivo e o Legislativo, "isto é, entre o que faz e o que cumpre o orçamento"57.

João Mangabeira criticava o modelo de censura à imprensa que então vigorava, observando que não havia país no mundo no qual a censura se fazia como no Brasil; aqui [em 1932], prosseguia Mangabeira "um funcionário qualquer de polícia, manda suspender, sem o menor motivo, a publicação de um editorial, já se tendo, mesmo, negado a publicação até de acórdãos do Supremo Tribunal Federal e discursos de senadores e deputados!"58.

À época debateu-se também a gratuidade do casamento civil; Mangabeira registrou que havia proliferação de uniões não regularizadas em cartório porque o casamento civil era caro, no que foi apoiado por Oswaldo Aranha, que lembrou que em seu estado de origem (Rio Grande do Sul) havia notícia de nubentes que atravessavam a fronteira e se casavam na Argentina ou no Uruguai ${ }^{59}$. Ainda em tema de casamento Mangabeira insistiu que previsão de indissolubilidade de matrimônio não era matéria constitucional; combatia também distinções entre filhos legítimos e ilegítimos, que então constavam das certidões de nascimento, alegando que o modelo engendrava uma das formas mais covardes da miséria humana, punindo um inocente, que de nada é culpado, e que "[...] no entanto, é o único a ser punido" ${ }^{60}$.

$\mathrm{Na}$ Comissão do Itamaraty o Exército foi representado pelo General Pedro Aurélio de Góis Monteiro, que se declarou "um tanto constrangido no seio da comissão por não ser jurista, sociólogo e legislador", julgando-se "apenas um informante ou portador da opinião de sua classe" ${ }^{" 61}$. Constrangido, evitava opinar sobre assuntos que não dominava, a exemplo do problema da unidade ou da duplicidade do sistema judicial; também, declarava-se absolutamente contrário aos militares se intrometerem na vida político-partidária, mesmo que não fosse de forma facciosa ${ }^{62}$.

\footnotetext{
$5615^{\text {a }}$ Sessão, de 29 de dezembro de 1932.

$5715^{\text {a }}$ Sessão, de 29 de dezembro de 1932.

$5820^{\text {a }}$ Sessão, sem indicação de data de realização.

$5936^{\text {a }}$ Sessão, sem indicação de data de realização.

${ }^{60} 36^{\text {a }}$ Sessão, sem indicação de data de realização.

$611^{\text {a }}$ Sessão, de 11 de novembro de 1932.

${ }^{62} 22^{\text {a }}$ Sessão, de 23 de janeiro de 1933.
} 
Góis Monteiro defendia a contenção dos militares, fazendo-o de um modo prosaico, centrado na premissa da vaidade do brasileiro; para Góis Monteiro "[...] o brasileiro é profundamente vaidoso e não são vaidosos apenas os civis e os homens cultos [...] até o Jeca Tatu tem incurável vaidade [...] o militar também [...] por isso é preciso contê-lo dentro da mais rígida disciplina" ${ }^{93}$.

A consulta aos debates da Comissão nos revela que Góis Monteiro participou ativamente das discussões em torno de questões militares, de defesa nacional e de garantias constitucionais, a exemplo do tema do estado de sítio. Góis Monteiro insistia na importância das Forças Armadas, afirmando que "[...] ou se tem de aceitar a ideia de que não há guerra e não é preciso força armada, ou, então, a ideia de que é possível a guerra [...] e ela é uma contingência da própria humanidade" ${ }^{14}$. Opinava pela necessidade de mudança da capital para o interior, argumentando que as exigências de segurança nacional deveriam primar sobre tudo $0^{65}$. $\mathrm{O}$ assunto exigia trato constitucional, insistia, alegando que a Constituição de 1891 era omissa na matéria ${ }^{66}$. Entendia que o estado de guerra era assunto gravíssimo e de ocorrência ocasional, dependendo de medidas severas que deveriam ser tomadas desde os tempos de paz, fixadas pela Constituição ${ }^{67}$.

Afirmou que "sendo o estado de guerra uma situação de vida ou de morte que o país atravessa, ficam naturalmente suspensos todos os direitos e garantias constitucionais, que, direta ou indiretamente, possam prejudicar o desenvolvimento das operações militares" ${ }^{\prime 68}$; nesse sentido, é tenaz defensor de poderes de exceção. Também defendia regras sobre o estado de sítio, dizendo se tratar de "uma medida necessária, [que] deve ser examinada sobre outros aspectos, como nos casos de insurreição armada do povo e das forças militares e, sobretudo, visando a guerra ou suas consequências"69; pretendia que essas regras fossem fixadas por lei ordinária, com base em disposição constitucional, para que o Poder Executivo ficasse inibido de decretar o estado de sítio quando bem entendesse, a seu arbítrio ${ }^{70}$.

Opinava que tropas estrangeiras poderiam atuar pelo território nacional, por

\footnotetext{
63 41 ${ }^{\mathrm{a}}$ Sessão, de 30 de março de 1933.

${ }^{64} 9^{\text {a }}$ Sessão, de 08 de dezembro de 1932.

${ }_{65} 3^{\text {a }}$ Sessão, de 18 de novembro de 1932.

${ }^{66} 4^{\mathrm{a}}$ Sessão, de 21 de novembro de 1932.

${ }^{67} 9^{\text {a }}$ Sessão, de 08 de dezembro de 1932.

${ }^{68} 11^{\text {a }}$ Sessão, de 15 de dezembro de 1932.

${ }^{69} 15^{\text {a }}$ Sessão, de 29 de dezembro de 1932.

$7015^{\text {a }}$ Sessão, de 29 de dezembro de 1932.
} 
concessão do Presidente, precedido de autorização da Assembleia ${ }^{71}$. Centralizador, também defendia que à União caberia a responsabilidade de chefiar todas as forças militares do país ${ }^{72}$. Era contrário ao sistema federativo, tal como organizado na Constituição de $1891^{73}$. Propugnava pela autonomia do Distrito Federal, "com as restrições necessárias, devidas à circunstância de ser a Capital da República" ${ }^{\text {. }}$.

Era favorável à representação classista, no que afinava com Getúlio Vargas ${ }^{75}$, ainda que afirmasse que a fórmula não poderia ser rígida, devendo ser eventualmente rediscutida e até revista ${ }^{76}$. Defendia o serviço militar obrigatório, a partir dos 14 anos, para ambos os sexos ${ }^{77}$.

A posição do governo na Comissão foi substancialmente defendida por Oswaldo Aranha, que repudiava o uso da Constituição de 1991 como base para as discussões, o que no seu entender significaria "uma simples reforma constitucional" Sempre reafirmando os compromissos revolucionários ${ }^{79}$, Aranha insistia que a Comissão deveria seguir ao programa do governo, dada as reponsabilidades assumidas com a vitória do movimento revolucionário ${ }^{80}$. Era um centralizador: temia que se desse muito poder aos Estados, circunstância que julgava um dos grandes problemas da República Velha ${ }^{81}$.

Aranha propôs a eliminação do Senado ${ }^{82}$; também se declarou pela mudança da capital, ainda que admitindo que o assunto não qualificasse matéria constitucional, opinando pela momentânea escolha de alguma cidade já existente, o que "[...] tornaria mais fácil e rápida a providência" ${ }^{\prime 3}$. Queria regra constitucional que obrigasse o deputado a participar das sessões ${ }^{84}$. Pretendia um mandato presidencial de seis anos, no que foi vencido, porquanto a Comissão aprovou encargo presidencial de apenas quatro anos ${ }^{85}$. A Comissão aprovou disposição que fixava o mandato presi-

\footnotetext{
$\overline{{ }^{71} 9^{\mathrm{a}} \text { Sessão, de } 08 \text { de }}$ dezembro de 1932.

$729^{\text {a }}$ Sessão, de 08 de dezembro de 1932.

$7315^{\text {a }}$ Sessão, de 29 de dezembro de 1932.

${ }^{74} 11^{\text {a }}$ Sessão, de 15 de dezembro de 1932.

$756^{\text {a }}$ Sessão, de $1^{\mathrm{O}}$ de dezembro de 1932.

${ }^{76} 9^{\text {a }}$ Sessão, de 08 de dezembro de 1932.

$777^{\mathrm{a}}$ Sessão, de 03 de dezembro de 1932.

${ }^{78}$ HILTON, Stanley. Oswaldo Aranha, uma biografia. Rio de Janeiro: Objetiva, 1994, p. 159.

${ }^{79} 22^{\text {a }}$ Sessão, de 23 de janeiro de 1933.

${ }^{80} 1^{\text {a }}$ Sessão, de 11 de novembro de 1932.

${ }^{81} 13^{\text {a }}$ Sessão, de 22 de dezembro de 1932.

${ }^{82} 5^{\text {a }}$ Sessão, de 28 de novembro de 1932.

${ }^{83} 6^{\text {a }}$ Sessão, de $1^{\mathrm{o}}$ de dezembro de 1932.

${ }^{84} 8^{\text {a }}$ Sessão, de 07 de dezembro de 1932.

${ }^{85} 14^{\text {a }}$ Sessão, de 26 de dezembro de 1932.
} 
dencial em um quadriênio, vedando reeleição senão seis anos depois de terminado o seu período presidencial (art. 37 do Projeto).

Oswaldo Aranha defendeu regra (que foi mais tarde aprovada no texto da Constituição de 1934) que responsabilizava os Ministros de Estado pela execução de seus orçamentos, inclusive o da Fazenda, na aplicação e estimativa da receita ${ }^{86}$. Defendeu entusiasticamente o mandado de segurança, que comparava com o right of mandamus do direito norte-americano e com o juício de amparo do direito mexicano ${ }^{87}$. Defensor de valores que prestigiavam conceitos então convencionais e dominantes de família, Aranha, no entanto, declarou em sessão que entendia que os filhos ilegítimos deveriam usufruir de vantagens correspondentes às dos legítimos, porque era a irresponsabilidade quem criara esses filhos desprotegidos ${ }^{88}$.

Houve momento no qual a Comissão discutiu participação dos funcionários fazendários nas multas lançadas e recolhidas de contribuintes faltosos, situação combatida por Oswaldo Aranha, que temia multas irregulares, adiantamento de valores e posterior anulação das penalidades, o que resultaria em prejuízos para o Fisco ${ }^{89}$. Oswaldo Aranha não aceitava imunidade fiscal para os magistrados; temia que se desse muito poder ao Supremo Tribunal Federal, inclusive por conta de um ilimitado modelo de controle de constitucionalidade de leis, o que poderia resultar, segundo afirmou em sessão, na "instituição da República Judiciária do Brasil" .

$\mathrm{Na}$ Comissão, o pensamento conservador era defendido por Oliveira Vianna, patrono de políticas de eugenia, discípulo de Alberto Torres, com quem comungava de fortíssima ideologia nacionalista, como fator moral de confiança em um projeto nacional ${ }^{91}$. Vianna era um crítico do sufrágio universal, cuja ideologia reputava vinda de "[...] estranhas terras, que nada tinham conosco e que desconheciam nossa formação social" 92 .

Partidário da centralização, Vianna negava direitos privativos das unidades federadas em face da União, reconhecendo tão somente os direitos que a União concederia aos Estados para uma melhor gestão dos interesses locais; enfatizava que os Estados não contavam com base tributária, e que não tinham condições de

\footnotetext{
${ }^{86} 16^{\text {a }}$ Sessão, de 02 de janeiro de 1933.

${ }^{87} 20^{\text {a }}$ Sessão, sem indicação de data de realização.

${ }^{88} 36^{\mathrm{a}}$ Sessão, sem indicação de data de realização.

${ }^{89} 25^{\text {a }}$ Sessão, de 31 de janeiro de 1933.

$9026^{\text {a }}$ Sessão, de 02 de fevereiro de 1932.

${ }^{11}$ TORRES, Alberto. O Problema Nacional Brasileiro. São Paulo: Cia. Nacional, 1978, p. 71

92 VIANNA, Oliveira. Instituições Políticas Brasileiras. São Paulo: Ed. da Universidade de São Paulo; Niterói: Ed. da Universidade Federal Fluminense, 1987, p. 240.
} 
manter serviços regulares de polícia e de ensino ${ }^{93}$. Quanto à representação classista propôs um modelo gradual, que começaria com representações municipais, para tratar de assuntos locais, com posterior e paulatina ampliação, no contexto do que denominava de "revolução demorada"

Oliveira Vianna defendia eleições indiretas para Presidente, com titularidade eleitoral de um eleitorado especial, escolhido junto a uma minoria, qualificada pelos cargos e posições que ocupa, mais representativa do que "[...] as maiorias inconscientes do interior e das cidades", segundo afirmou em sessão ${ }^{95}$. Assertivo, enfatizou que era contrário à eleição do Presidente da República pelo sufrágio direto, bem como era contrário à eleição do chefe do executivo por uma Assembleia Nacional; para Oliveira Vianna o sufrágio direto ou de uma assembleia não qualificada era fonte de agitações inúteis, com nenhuma significação de resultados ${ }^{96}$.

Oliveira Vianna apresentou proposta interessante quanto à composição e escolha dos Ministros do Supremo Tribunal Federal. Propunha 15 juízes, brasileiros natos, de notável saber jurídico e maiores de 55 anos, escolhidos em uma lista de cinco nomes, organizada pelo próprio Tribunal; a lista seria levada para um Conselho Supremo que em escrutínio secreto escolheria os nomes que comporiam nosso Tribunal maior ${ }^{97}$. Também não admitia que qualquer interessado pudesse provocar o Supremo em questões de constitucionalidade, prevendo que essa função poderia ser exercida pelo Instituto dos Advogados; à época ainda não havia a Ordem dos Advogados do Brasil (OAB).

Oliveira Vianna também ofereceu importantes contribuições em matéria de direito do trabalho, uma de suas especialidades. Nas discussões referentes ao salário mínimo discordou da fixação de um salário nacionalmente unificado, entendendo que os valores deveriam estar "[...] de acordo com as condições de vida de cada região" $"$.

A participação de José Américo de Almeida na Comissão foi modesta, por conta de reiteradas faltas nas sessões, em decorrência de outras funções que exercia no governo, como realçado por Afrânio de Mello Franco na sessão de encerramento

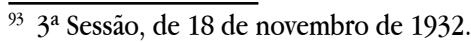

${ }^{94} 6^{\mathrm{a}}$ Sessão, de $1^{\mathrm{o}}$ de dezembro de 1932.

${ }^{95} 12^{\text {a }}$ Sessão, de 19 de dezembro de 1932.

$9613^{\text {a }}$ Sessão, de 22 de dezembro de 1932.

${ }^{97} 26^{\text {a }}$ Sessão, de 02 de fevereiro de 1932.

${ }^{98} 38^{\text {a }}$ Sessão, sem indicação de data de realização.
} 
dos trabalhos ${ }^{99}$. Em uma de suas raras intervenções declarou-se partidário da representação política classista, um dos grandes temas discutido por aquele colegiado ${ }^{100}$.

Artur Ribeiro deixou a Comissão por discordar da forma de organização do judiciário, fazendo-o por longa carta, lida em sessão, na qual invocava, como argumento central de seu afastamento, uma questão de ordem doutrinária ${ }^{101}$.

Temístocles Brandão Cavalcanti, então com pouco mais de 30 anos, participou entusiasticamente das discussões. Cavalcanti exerceu importantíssimos cargos, ao longo de vida dedicada ao direito; foi Consultor-Geral da República, ProcuradorGeral da República e Ministro do Supremo Tribunal Federal. Mostrou-se favorável a um projeto de mudança de capita ${ }^{102}$. Quanto ao Poder Legislativo, opinava, "sem atender a outras considerações que não as de caráter ideológico [...] por uma pequena Assembleia, técnica, profissional, organizada por meio de representação de classes" ${ }^{103}$.

Opinou interessantemente no tema do ensino religioso, votando por um ensino facultativo, "ministrado fora das horas de curso normal para não criar dentro das escolas o espírito de indisciplina e da luta religiosa". Ainda que religioso, votou contra a proposta de inclusão de regra de indissolubilidade do casamento, por reputá-la por demais rígida ${ }^{104}$; nesse aspecto, venceu na Comissão e mais tarde na Constituinte. Cavalcanti defendeu a socialização das minas e das quedas d'água, propondo, no entanto, que se respeitassem os direitos adquiridos daqueles que já as explorassem ${ }^{105}$. O conceito preciso de "direitos adquiridos", como enfatizado por Cavalcanti em sessão, deveria ser averiguado e explicitado ${ }^{106}$.

Revelou-se como grande entusiasta do referendo popular, "com seus naturais limites, principalmente num país [...] de educação política rudimentar" ${ }^{107}$, passagem que indica um pensamento substancialmente conservador, ainda que marcado pelo contexto político da década de 1930. Cavalcanti defendeu arranjos institucionais municipalistas, propondo que os municípios tivessem existência autônoma ${ }^{108}$.

\footnotetext{
$9951^{\text {a }}$ Sessão, de 05 de maio de 1933.

${ }^{100} 6^{\mathrm{a}}$ Sessão, de $1^{\mathrm{o}}$ de dezembro de 1932.

${ }^{101} 23^{\text {a }}$ Sessão, sem indicação de data de realização.

$1023^{\text {a }}$ Sessão, de 18 de novembro de 1932.

103 4 ${ }^{\mathrm{a}}$ Sessão, de 28 de novembro de 1932.

${ }^{104} 36^{\text {a }}$ Sessão, sem indicação de data de realização.

${ }^{105} 37^{\text {a }}$ Sessão, de 17 de março de 1931.

$10639^{\text {a }}$ Sessão, de 23 de março de 1933.

${ }^{107} 40^{\text {a }}$ Sessão, de 27 de março de 1933.

$10841^{\text {a }}$ Sessão, de 30 de março de 1933.
} 
Quanto ao municipalismo, predominou, à época, tendência que culminou na garantia do princípio da eletividade da administração municipal, com exceções expressamente consagradas no texto final, verificando-se também o superveniente triunfo de disposições que aumentavam as receitas dos municípios ${ }^{109}$.

A inteligência jurídica também foi representada por José de Castro Nunes, que mais tarde integrou o Tribunal de Contas da União e o Supremo Tribunal Federal. Admirador de Rui Barbosa, em quem captou uma "vocação apostolar que ia até o sacrifício, como todas as grandes vocações" ${ }^{" 110}$, Castro Nunes invocava a autoridade de Rui para defender o controle de constitucionalidade, por parte do Supremo Tribunal Federal ${ }^{111}$.

Também discutiu intensamente o tema da presença de empresas estrangeiras no Brasil, argumentando que exigências de nacionalização contemplavam mais sequelas burocráticas e de papel, do que efeitos efetivamente práticos ${ }^{112}$. Combateu a doutrina da fixação de um salário mínimo nacional, invocando a dificuldade em se atender a todas as circunstâncias regionais, preferindo "o aparelho mais flexível das juntas de conciliação e arbitramento, estabelecendo o salário que deve ser pago e se adapta a cada região" ${ }^{113}$. Curiosamente, Castro Nunes problematizou o lema da bandeira nacional, lembrando as críticas que Silvio Romero fizera à divisa "ordem e progresso", no sentido de que o dito não corresponderia ao sentimento de nacionalidade, alegando que "a ordem é o meio; o progresso [...] o fim"114.

Um dos mais destacados e combativos membros da Comissão do Itamaraty foi o jurista Carlos Maximiliano, que mais tarde também chegou ao Supremo Tribunal Federal. Maximiliano criticou a criação do Senado ${ }^{115}$, bem como a eleição direta para Presidente da República, que reputava "condenada pela nossa história e pela experiência universal"116.

Carlos Maximiliano referiu-se à Fazenda Nacional como uma "viúva abandonada" que os juízes em geral se inclinam a julgar contra ela; problematizou a aposentadoria dos Ministros do Supremo, com proventos integrais, lembrando que o

\footnotetext{
${ }^{109}$ LEAL, Victor Nunes. Coronelismo, enxada e voto : o município e o regime representativo no Brasil. São Paulo: Companhia das Letras, 2012, p. 97-98

${ }^{110}$ NUNES, J. de Castro. Alguns homens de meu tempo. Rio de Janeiro: José Olympio, 1957, p. 17

$11144^{\mathrm{a}}$ Sessão, de 06 de abril de 1933.

${ }^{112} 37^{\text {a }}$ Sessão, de 17 de março de 1931.

${ }^{113} 38^{\mathrm{a}}$ Sessão, sem indicação de data de realização.

${ }_{114} 44^{\text {a }}$ Sessão, de 06 de abril de 1933.

115 4a $^{\mathrm{a}}$ Sessão, de 28 de novembro de 1932.

${ }^{116} 13^{\text {a }}$ Sessão, de 22 de dezembro de 1932.
} 
governo pode nomear como Ministro "um amigo valetudinário" que no fim de dois anos iria se aposentar com os valores totais ${ }^{117}$. Defendia que os funcionários da Fazenda deveriam receber participação nas multas cobradas, o que funcionaria como um incentivo na arrecadação ${ }^{118}$.

Crítico de um texto longo, Maximiliano se queixava que o anteprojeto era imenso, que estava três vezes mais volumoso do que a Constituição de 1891, porquanto até de prazos se dispunha a tratar ${ }^{119}$. Lembrou que por educação e formação de espírito era contrário às leis prolixas, e que a Constituição "era uma lei básica, feita para durar 50 ou 100 anos"120. Propôs para o Supremo Tribunal Federal uma denominação que julgava mais elegante e concisa, "Corte Suprema" e, se não aceita a proposta, sugeria emenda conciliadora: "Tribunal Supremo"121.

A Comissão do Itamaraty conclui seus trabalhos apresentando um texto repleto de inovações, que rompia radicalmente com a tradição liberal da Constituição de 1891. Em oposição ao laicismo absoluto dos positivistas que dominaram a confecção da primeira Constituição da República, os membros da Comissão chegaram a elaborar um sofisticado título sobre a religião, centrado na premissa de independia da crença e do culto religioso o exercício de direitos individuais, sociais e políticos ( $\$ 1^{\circ}$ do art. 106 do Projeto).

Os membros da Comissão do Itamaraty conceberam um curioso Conselho Supremo, que seria composto de 35 conselheiros efetivos, e "mais extraordinários, quantos forem os cidadãos sobreviventes, depois de haverem exercido por mais de três anos a presidência da República"; com mandato de sete anos, esse Conselho seria órgão técnico e deliberativo com competências que variavam da aprovação (ou não) de Ministros de Estado a decidir sobre os recursos interpostos nos casos de censura imerecida (arts. 67 e 68 do Projeto).

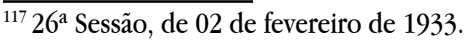

${ }^{118} 25^{\text {a }}$ Sessão, de 31 de janeiro de 1933.

${ }^{119} 22^{\text {a }}$ Sessão, de 23 de janeiro de 1933.

${ }^{120} 23^{\mathrm{a}}$ Sessão, sem indicação de data de realização.

${ }^{121} 21^{\text {a }}$ Sessão, de 19 de janeiro de 1933.
} 


\section{A ASSEMBLEIA CONSTITUINTE E O TEXTO DA CONSTITUIÇÃO DE 1934}

A Assembleia Constituinte funcionou ao longo de oito meses, entre $1933 \mathrm{e}$ 1934 e contou com 214 deputados gerais e 40 deputados classistas. Entre os parlamentares, nomes importantes da memória histórica nacional, como João Alberto Lins de Barros, Bias Fortes, Christiano Machado, Plínio Corrêa, Cincinato Braga, Carlota Pimenta de Queiróz (a primeira deputada da história do Brasil), Olegário Mariano, Agamenon Guimarães, Prado Kelly, Raul Fernandes, Pedro Aleixo, Odilon Braga, Nereu Ramos, Victor Russomano, Levi Carneiro, Euvaldo Lodi, Roberto Simonsen, Horácio Lafer, Carlos Maximiliano, entre tantos outros. A ideia central consistiu em modelo de contenção ao Executivo; o resultado, inesperado, foi a reação golpista de 1937, com a instalação do Estado Novo ${ }^{122}$.

Uma das vozes mais combativas na Assembleia de 1933-34 foi a de Levi Carneiro, que fora Consultor-Geral da República e que, nessa qualidade, fora importante opinião na criação da Ordem dos Advogados do Brasil, para a qual orientou o conhecimento que tinha da profissão, especialmente pela experiência que trazia do Instituto dos Advogados Brasileiros. Levi Carneiro protagonizou importantes intervenções, em temas os mais variados, a exemplo do problema dos subsídios dos deputados $^{123}$, da organização do Poder Judiciário ${ }^{124}$, da intervenção federal ${ }^{125}$, entre tantos outros. A Assembleia Nacional Constituinte de 1933-34 foi muito influenciada pelas ideias de Mirkine-Guetzévicth, então Secretário-Geral do Instituto Internacional de Direito Público em Paris, autor de livro que explorava as tendências do Direito Constitucional em um contexto de defesa de Estados intervencionistas ${ }^{126}$.

O texto final da Constituição de 1934, tal como aprovado pela Assembleia Nacional Constituinte, ficou muito diferente do documento elaborado pela Comissão do Itamaraty. A Comissão construiu texto substancialmente mais simples e enxuto, com 136 artigos. Autores finais do texto da Constituição de 1934 não levaram em conta as preocupações de Carlos Maximiliano e elaboraram texto extenso (187 artigos, contra os 91 artigos da Constituição de 1891), no qual havia muita matéria de índole não constitucional.

Fortíssima foi a presença do constitucionalismo de Weimar, especialmen-

\footnotetext{
${ }^{122}$ POLETTI, Ronaldo. Constituições Brasileiras, vol. III, 1934. Brasília: Senado Federal, 2012, p. 33.

${ }^{123}$ Sessão de 14 de maio de 1934.

${ }^{124}$ Sessão de 20 de abril de 1934.

${ }^{125}$ Sessão de 11 de maio de 1934.

${ }^{126}$ GUETZÉVITCH, B. Mirkine. As novas tendências do Direito Constitucional. Tradução de Candido Motta Filho. São Paulo: Companhia Nacional, 1933.
} 
te porque "[...] se o neopresidencialismo weimariano era útil ao messianismo que então se criava em torno de Vargas, seu neocorporativismo convinha ao imemorial patrimonialismo ibero-americano" 127 . Para outro autor, "a nova Carta Magna [Constituição de 1934] sofreu decisiva influência da Constituição de Weimar, é um reflexo sul-americano dela, catalogando-se nosso regime não mais como uma democracia liberal, e sim como uma democracia social, com a poderosa ampliação da atividade do governo no campo econômico" ${ }^{228}$.

A Constituição de 1934, no entanto, contém arranjos institucionais inovadores que revelam esforço brasileiro para enfrentar com criatividade problemas de engenharia social. A Constituição de 1934 poderia ser reformada de dois modos: poderia ser emendada e poderia ser revisada (art. 178). As emendas não poderiam alcançar regras de estrutura política do Estado, organização ou a competência dos poderes da soberania, bem como a própria norma que dispôs sobre emendas e revisão. Assim, esses temas centrais somente poderiam ser alterados por via de revisão, e não por emenda, pelo que cláusulas pétreas eram sensíveis a alterações; isto é, revisões constitucionais funcionavam como britadeiras institucionais. Essa premissa não se aplicava a projetos que tivessem como objeto de deliberação a abolição da forma republicana federativa ( $\$ 5^{\circ}$ do art. 178).

As emendas deveriam ser formuladas de modo preciso, com iniciativa de quarta parte, pelo menos, dos membros da Câmara e do Senado, ou de mais da metade dos Estados, no decurso de dois anos, quando cada uma das unidades federadas deveria se manifestar pela maioria das assembleias respectivas $\left(\S 1^{\circ} \mathrm{do}\right.$ art. 178). Propostas de revisão deveriam ser apresentadas na Câmara ou no Senado, com apoio de pelo menos de dois quintos dos membros, ou submetidas a eles por dois terços das assembleias legislativas ( $\$ 2^{\circ}$ do art. 178). Observa-se que às assembleias legislativas estaduais reservava-se amplo poder de encaminhamento e decisão relativos a emendas e revisão do texto constitucional.

No projeto da Comissão do Itamaraty proibia-se a declaração de inconstitucionalidade de lei federal aplicada sem reclamação a mais de cinco anos; além do que, no âmbito do controle difuso, segundo o projeto não aprovado, sempre que qualquer tribunal ou juiz não aplicasse lei federal ou ato do Presidente, por inconstitucionais, deveria recorrer de ofício, e com efeito suspensivo, para o Supremo

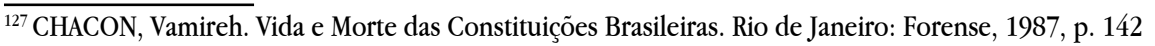
${ }^{128}$ FERREIRA, Pinto. Princípios gerais do Direito Constitucional Moderno. São Paulo: Revista dos Tribunais, 1971, p. 112. 
Tribunal Federal (art. 57 do Projeto da Comissão do Itamaraty).

No contexto de um capítulo autônomo de Coordenação dos Poderes, a Constituição de 1934 cogitou de Órgãos de Cooperação nas Atividades Complementares, no qual inseriu o Ministério Público, o Tribunal de Contas e Conselhos Técnicos. Resolvia-se, assim, o problema da natureza jurídica do Ministério Público e do Tribunal de Contas, que pairavam sobre os três poderes, exercendo suas funções, na qualidade de órgãos de cooperação. O Procurador-Geral da República teria os mesmos vencimentos dos Ministros do Supremo Tribunal e os Procuradores-Gerais nos Estados os mesmos vencimentos dos Desembargadores ( $\$ \S 1^{\circ}$ e $2^{\circ}$ do art. 95). No texto do projeto não aprovado, dispunha-se que o Ministério Público era o órgão da lei e da defesa social (art. $63 \S 3^{\circ}$ do Projeto). O Tribunal de Contas figurava como órgão de acompanhamento da execução orçamentária e julgamento das contas dos responsáveis por dinheiros ou bens públicos (art. 99). A novidade estava nos Conselhos Técnicos, a quem incumbiria assistir os Ministérios, como órgãos consultivos, proibindo-se que Ministros de Estado deliberassem, em matéria de competência exclusiva, contra parecer unânime do respectivo Conselho (art. 103).

Exemplos de matéria de índole não constitucional no texto aprovado de 1934 podem ser colhidos, a propósito, no caso de regra que vedava a concentração de imigrantes em qualquer ponto do território da União, dispondo também que a lei deveria regular a seleção, localização e assimilação do "alienígena" ( $\$ 7^{\circ} \mathrm{do}$ art. 121). No mesmo sentido, norma que fixava que nos acidentes de trabalho em obras públicas da União, dos Estados e dos Territórios, a indenização seria feita pela folha de pagamento, quinze dias contados da sentença, da qual não se admitiria recurso ex-officio ( $\$ 8^{\circ}$ do art. 121).

Estabeleceu-se que a família seria constituída pelo casamento indissolúvel, e que estaria sob a proteção do Estado (art. 144). A regra do casamento indissolúvel pode revelar vitória se segmentos católicos, a influência do Cardeal Leme, e a ação de ativistas católicos, como Alceu Amoroso Lima. No texto da Comissão do Itamaraty, não se fixou a indissolubilidade do casamento, dispondo-se, de modo mais liberal, que a família estava sob proteção especial do Estado, que repousava sobre o casamento e sobre a igualdade jurídica dos sexos; no entanto, a lei civil poderia estabelecer condições de chefia da sociedade conjugal e do pátrio poder, regulando direitos e deveres dos cônjuges (art. 107 do Projeto da Comissão do Itamaraty).

Conservadoras e alinhadas com o catolicismo eram, de igual modo, disposi- 
ções sobre ensino religioso, o qual, ainda que de frequência facultativa, seria matéria dos horários nas escolas públicas primárias, secundárias, profissionais e normais (art. 153), revertendo-se uma proibição da Constituição de $1891^{129}$. Não se pode deixar de levar em conta também a aproximação entre Gustavo Capanema (político muito ligado a Vargas) e Alceu Amoroso Lima ${ }^{130}$, o que poderia ter resultado no triunfo do ideário católico que avançou em meados da década de 1930. Gustavo Capanema foi elemento de ligação que possibilitou uma aliança entre a Igreja e a ordem representada por Vargas ${ }^{131}$. Alceu Amoroso Lima liderava os católicos, na qualidade de Presidente do Centro D. Vidal, grupo que condenava o laicismo da República Velha, e que pretendia uma Constituição promulgada em nome de Deus, na qual o casamento seria indissolúvel ${ }^{132}$; triunfaram em muitos pontos.

A Constituição de 1934 também revela alguma motivação eugênica, como se colhe em artigo que dispunha que a lei regularia a apresentação pelos nubentes de provas de sanidade física e mental, com curiosa determinação para que se atendesse as condições regionais do país (art. 145). Explicitamente, determinava-se que os poderes públicos estimulariam a "educação eugênica" (art. 138, $b$ ) e que cuidariam da higiene mental e incentivariam a luta contra os "venenos sociais" (art. 138, g), o que pode significar construção constitucional de combate a doenças venéreas.

Era também sintoma de época a evocação do patriotismo, na medida que se obrigava a todo brasileiro jurar a bandeira nacional, na forma e sob as penas da lei ( $1^{\mathrm{a}}$ do art. 163), não se permitia o acesso ao serviço público a quem não comprovasse quitação plena para com "obrigações estatuídas em lei para com a segurança nacional" ( $\$ 2^{\circ}$ do art. 163$)$.

Trata-se de um texto substancialmente de época, nacionalista, com restrições à liberdade econômica, cuja ordem deveria ser organizada "conforme os princípios da justiça e as necessidades da vida social" (art. 115). Planejava-se a "nacionalização progressiva dos bancos de depósito", a "nacionalização das empresas de seguro em todas as suas modalidades", bem como deveriam constituir-se em sociedade brasileira as estrangeiras que no Brasil operassem (art. 117).

$\mathrm{O}$ intervencionismo revelava-se também em regra que dispunha que a lei deveria promover o amparo da produção, estabelecendo condições de trabalho, na

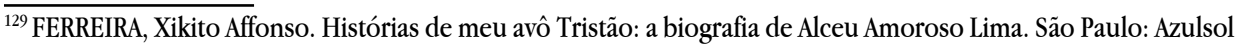
Editora, 2015, p. 87

${ }^{130}$ BADARÓ, Murilo. Gustavo Capanema, a revolução na cultura. Rio de Janeiro: Nova Fronteira, 2000, p. 265.

${ }^{131}$ SCHWARTZMAN, Simon et al. Tempos de Capanema. São Paulo: Paz e Terra, 2000, p. 61.

${ }^{132}$ ANDRADE, [s. d.], p. 67. 
cidade e no campo, "tendo em vista a proteção social do trabalhador e os interesses econômicos do país" (art. 121). A legislação trabalhista que será sistematizada na Consolidação das Leis do Trabalho era elencada, inclusive com disposições sobre salário-mínimo, o qual, no entanto, deveria atender "as condições de cada região" (art. 121). Estrangeiros não poderiam possuir empresas jornalísticas políticas ou noticiosas (art. 131). Havia previsão para lei que determinaria a percentagem de empregados brasileiros que deveriam ser mantidos nos serviços públicos dados em concessão, "e nos estabelecimentos de determinados ramos de comércio e indústria" (art. 135).

Aos mendigos era proibido o alistamento eleitoral (art. 108, c); tal vedação, no entanto, não fora prevista no projeto (art. 98 do Projeto da Comissão do Itamaraty). $\mathrm{O}$ voto feminino foi reconhecido, ainda que de modo mitigado; às mulheres o voto era obrigatório apenas quando exercessem função pública remunerada (art. 109). Um publicista da época defendia o voto feminino, desde a década de 1920 , observando que era também preciso não se ter filosofia nenhuma para achar que o voto feminino era uma coisa ruim ${ }^{133}$.

Paradoxalmente, no capítulo dos direitos e garantias individuais era assegurado o direito de subsistência, ao lado dos direitos de liberdade, segurança individual e propriedade (art. 113). Era garantida a liberdade de consciência e crença, bem como o livre exercício dos cultos religiosos, desde que não ofendessem "a ordem pública e aos bons costumes" (art. 113, 5). Proibia-se que as ordens religiosas recusassem sepultura onde não houvesse cemitério secular (art. 113, 7). A aproximação com o catolicismo era observada por disposição constitucional que afirmava que seria mantida a representação diplomática junto à Santa Sé (art. 176). No preâmbulo registrou-se que o Povo Brasileiro colocava "confiança em Deus".

$\mathrm{Na}$ organização do Poder Judiciário uma "Corte Suprema" estava no topo da hierarquia (art. 63); a aposentadoria compulsória dos ministros se daria aos 75 anos de idade (art. 64, a). A Constituição de 1934 dispôs sobre mandado de segurança, o qual seria dado para defesa de direito, que fosse certo e incontestável, ameaçado ou violado por ato manifestadamente inconstitucional ou ilegal de qualquer autoridade; dispunha-se que o processo seria igual do babeas corpus e que não prejudicaria as ações petitórias competentes (art. 113, 33). Proibia-se o non liquet, isto é, nenhum juiz deixaria de sentenciar por omissão de lei, quando então deveria sentenciar com

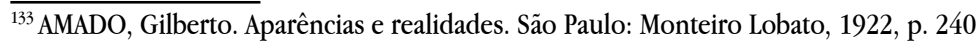


base na analogia, nos princípios gerais de direito e na equidade (art. 113, 37).

Não se aproveitou a concepção do projeto originário, que previa um Supremo Tribunal, na Capital da União, onde também funcionaria um Tribunal de Reclamações, a par de Tribunais da Relação, nas Capitais dos Estados e nas dos Territórios, e no Distrito Federal, além de toda a estrutura da Justiça Estadual (art. 48 do Projeto da Comissão do Itamaraty). Os autores da Comissão do Itamaraty também vedaram qualquer outra função pública para os juízes, sempre incompatíveis, penalizando-se o magistrado com a perda do cargo judicial (art. 51 do Projeto). Com efeito "mantinha-se o velho e defeituoso sistema de duas justiças paralelas, uma estadual e outra federal e conservava-se a Corte Suprema, congestionada por excesso de competências originárias e pela própria superposição de tribunal de segunda instância"134.

A responsabilidade do servidor público era solidária à da Fazenda, por quaisquer prejuízos decorrentes de negligência, omissão ou abuso no exercício do cargo; o funcionário era litisconsorte nas ações propostas contra a Fazenda, nessas hipóteses (art. 171). Deu-se feição constitucional à Justiça Eleitoral (art. 82), que substituiu a Comissão Verificadora dos Poderes da República Velha. De igual modo, tem-se também a Justiça Militar (art. 84), que teria como órgãos o Supremo Tribunal Militar e os tribunais e juízos inferiores, que deveriam ser instituídos por lei (art. 86). Criou-se um Tribunal Especial, com função de julgar servidores que teriam cometidos atos delituosos na ordem constitucional da República Velha; este Tribunal poderia aplicar somente penas de perda de cargo, com inabilitação por até cinco para o exercício de funções públicas, sem prejuízo de outras sanções civis e penais cabíveis ( $\$ 7^{\circ}$ do art. 58).

Entre outras peculiaridades, dispunha-se que a Nação brasileira seria constituída pela união perpétua e indissolúvel dos Estados, do Distrito Federal e dos Territórios (art. $1^{\circ}$ ); não se reconhecia o Município como unidade federada, ainda que estes pudessem ser organizados de forma que lhes ficasse assegurada a autonomia em tudo que respeitasse o peculiar interesse local (art. 13). No tema da tripartição dos poderes, dispunha-se que estes, Legislativo, Executivo e Judiciário, eram "órgãos da soberania nacional, dentro dos limites constitucionais", e que deveriam ser "independentes e coordenados entre si" (art. $3^{\circ}$ ).

Quanto aos índios, proclamou-se o objetivo de incorporá-los à comunhão nacional (art. $\left.5^{\circ}, \mathrm{XIX}, m\right)$, dispondo-se sobre o respeito a suas terras, desde que

${ }^{134}$ PACHECO, Cláudio. Tratado das constituições brasileiras. Rio de Janeiro e São Paulo: Livraria Freitas Bastos, 1958, p. 259 
nelas se achassem, permanentemente localizados, vedando, em qualquer hipótese, a alienação dessas terras (art. 129). Cada Ministro deveria responder pelas despesas de seu Ministério; o Ministro da Fazenda, além disso, era responsável "pela arrecadação da receita" (art. 61).

O traço mais característico da Constituição de 1934 era a representação classista, que não fora pensada pela Comissão do Itamaraty. No texto final, fixou-se que a Câmara dos Deputados seria composta por representantes do povo, "eleitos mediante sistema proporcional e sufrágio universal, igual e direto, e de representantes eleitos pelas organizações profissionais [...]" (art. 23).

Talvez, de fato, o texto aprovado insinuasse o "estado de desconfiança da Nação no chefe do poder executivo; mas, por outro lado, revelava que tinha sido excessivamente desfigurado na Constituição de 1934, o presidencialismo tão bem plasmado na de 1891 [...] desse estado de espírito nasceu o golpe de 1937"135. Essa opinião é compartilhada por outro autor, para quem "a Constituição, ao contrário do anteprojeto, pautou-se por uma desconfiança diante do Executivo [...] condicionando tudo ao Legislativo, que daria a última palavra, a Carta de 34, por motivos transversos, preparou o golpe de Estado de 37"136.

A Constituição de 1934, de curtíssima duração, foi vilipendiada pelos aliados de Vargas. Um deles, intelectual a serviço paradoxal de uma técnica de construção de um Estado totalitário a serviço da democracia, registrou, em texto inflamado, que

com três anos de execução nominal, só restava da Constituição e da máquina criada por ela uma carcaça imensa a que a vida fugira, mas que continuava a pesar sobre os ombros do povo, confiscando-lhe, para manter-se, boa parte de sua fortuna e do seu trabalho, e tentando congelar-lhe, nas suas formas arcaicas, a espontaneidade da vida política $^{137}$.

Um dos mais importantes estudiosos do texto de 1934 sardonicamente observou que aquela Constituição nunca fora revisada, e nem emendada: fora rasgada, pelo golpe que Getúlio deu, em $1937^{138}$.

\footnotetext{
${ }^{135}$ FERREIRA, Waldemar Martins. História do Direito Constitucional Brasileiro. Brasília: Senado Federal, 2003, p. 99.

${ }^{136}$ POLETTI, Ronaldo. Constituições Brasileiras, vol. III, 1934. Brasília: Senado Federal, 2012, p. 29.

${ }^{137}$ CAMPOS, Francisco. O Estado Nacional. Brasília: Senado Federal, 2001, p. 46.

${ }^{138}$ POLETTI, op. cit., 2012, p. 41
} 


\section{CONCLUSÕES}

A Constituição de 1934 catalisou os dilemas políticos da década de 1930, captando tensões que decorriam do insuperável dissenso entre o liberalismo e o conservadorismo, tendências que albergavam e também disfarçavam as antíteses entre o capitalismo e o totalitarismo que começava a triunfar na Europa. É um documento de época, e que captou suas ambiguidades e perplexidades.

Negando percepção de que nossos modelos institucionais apenas reproduzem ideias fora de lugar, a Constituição de 1934 de fato enfrentou problemas latentes, a exemplo da organização da Justiça Eleitoral, do ritual do mandado de segurança, da legislação trabalhista e do voto feminino. Permeável a influências políticas e sociais que cooptavam com o governo provisório de Vargas, a exemplo do cristianismo (e seus efeitos sobre os conceitos de família, casamento, ensino religioso) e do trabalhismo (a exemplo da representação classista) a Constituição de 1934, no plano teórico, ajustou-se a um compromisso naquele tempo imaginado como possível.

A causa da Constituição de 1934 foi a mesma razão de seu aniquilamento. Sua gênese teve como motivo as mesmas circunstâncias que qualificaram seu ocaso. Quem possibilitou a articulação de forças que produziu seu texto foi o mesmo condutor das forças políticas que engendraram seu abandono. A Constituição de 1934 é um dos mais emblemáticos exemplos da manipulação de compromissos, exercício político recorrente na trajetória de líderes dotados de carisma, a exemplo de Getúlio Vargas, a usarmos uma tipologia tipicamente weberiana. No plano dogmático, substancializou-se por inovações que eram úteis, mas que se revelavam também como inevitáveis.

\section{REFERÊNCIAS}

AMADO, Gilberto. Aparências e Realidades. São Paulo: Monteiro Lobato, 1922.

AZEVEDO, José Afonso de Mendonça. Elaborando a Constituição Nacional: atas da Subcomissão elaboradora do anteprojeto 1932-1933. Brasília: Senado Federal, 2004. 
BADARÓ, Murilo. Gustavo Capanema, a Revolução na Cultura. Rio de Janeiro: Nova Fronteira, 2000.

BONAVIDES, Paulo; ANDRADE, Paes de. História Constitucional do Brasil. Rio de Janeiro: Paz e Terra, 1991.

BOURNE, Richard. Getúlio Vargas: a Esfinge dos Pampas. Tradução de Paulo Schmidt e Sonia Augusto. São Paulo: Geração, 2012.

CAMPOS, Francisco. O Estado Nacional. Brasília: Senado Federal, 2001.

CARNEIRO, Levi. Pela Nova Constituição. Rio de Janeiro: A. Coelho Branco Filho, 1936.

CARONNE, Edgard. A Segunda República - 193-1937. Rio de Janeiro e São Paulo: DIFEL, 1978.

CHACON, Vamireh. Vida e Morte das Constituições Brasileiras. Rio de Janeiro: Forense, 1987.

DULLES, John W. F. Vargas of Brazil: a Political Biography. Austin: University of Texas Press, 1967.

FAORO, Raymundo. Os Donos do Poder. Rio de Janeiro: Globo, 1997.

FAUSTO, Boris. Getúlio Vargas. São Paulo: Companhia das Letras, 2006.

FERREIRA, Pinto. Princípios Gerais do Direito Constitucional Moderno. São Paulo: Revista dos Tribunais, 1971.

FERREIRA, Waldemar Martins. História do Direito Constitucional Brasileiro. Brasília: Senado Federal, 2003.

FERREIRA, Xikito Affonso. Histórias de meu avô Tristão: a biografia de Alceu Amoroso Lima. São Paulo: Azulsol, 2015.

FRANCO, Afonso Arinos de Mello. Um Estadista da República. Rio de Janeiro: Nova Aguillar, 1976. 
GUETZÉVITCH, B. Mirkine. As Novas Tendências do Direito Constitucional. Tradução de Candido Motta Filho. São Paulo: Companhia Nacional, 1933.

HILTON, Stanley. Oswaldo Aranha, uma biografia. Rio de Janeiro: Objetiva, 1994.

LEAL, Victor Nunes. Coronelismo, Enxada e Voto: o Município e o Regime Representativo no Brasil. São Paulo: Companhia das Letras, 2012.

MANGABEIRA, João. Ideias Políticas de João Mangabeira. Brasília: Senado Federal e Rio de Janeiro: Casa de Rui Barbosa, 1980.

MANGABEIRA, João. Ruy, o Estadista da República. São Paulo: Martins Fontes, 1946.

MELLO, José Carlos. Os Tempos de Getúlio Vargas. Rio de Janeiro: Topbooks, 2011.

NUNES, J. de Castro. Alguns homens de meu tempo. Rio de Janeiro: José Olympio, 1957.

PACHECO, Cláudio. Tratado das Constituições Brasileiras. Rio de Janeiro e São Paulo: Freitas Bastos, 1958.

PEREIRA, Lígia Maria Leite; FARIA, Maria Auxiliadora de. Presidente Antônio Carlos, um Andrada da República, o Arquiteto da Revolução de 30. Rio de Janeiro: Nova Fronteira, 1998.

POLETTI, Ronaldo. Constituições Brasileiras, volume III, 1934. Brasília: Senado Federal, 2012.

ROURE, Agenor de. A Constituinte Republicana. Brasília: Senado Federal, 1979.

ROURE, Agenor de. Formação Constitucional do Brazil. Rio de Janeiro: Jornal do Comércio, 1914.

SCHWARTZMAN, Simon et al. Tempos de Capanema. São Paulo: Paz e Terra, 2000.

SODRÉ, Nelson Werneck. Formação Histórica do Brasil. Rio de Janeiro: Graphia, 2004. 
TORRES, Alberto. O Problema Nacional Brasileiro. São Paulo: Cia. Nacional, 1978.

VARGAS, Getúlio. Diário, volume I, 1930-1936. São Paulo: Siciliano e Rio de Janeiro: Fundação Getúlio Vargas, 1995.

VIANNA, Oliveira. Instituições Políticas Brasileiras. São Paulo: Ed. da USP; Niterói: Ed. da UFF, 1987.

WOLKMER, Antônio Carlos. A questão dos direitos sociais na Comissão Itamarati. Revista de Ciência Política, v. 27, n. 3, set./dez. 1984.

Recebido em: 07 de abril de 2016 Aceito em: 21 de dezembro de 2016 